\title{
Induction of Thymic Stromal Lymphopoietin Production by Xylene and Exacerbation of Picryl Chloride-Induced Allergic Inflammation in Mice
}

\author{
Nozomi Satou $^{a}$ Kenji Ishiharaa, c Masahiro Hiratsuka ${ }^{a}$ Hiroyuki Tanakad \\ Yasuo Endo $^{b}$ Saburo Saito ${ }^{e}$ Yoichiro Iwakura ${ }^{f}$ Warren J. Leonard ${ }^{g}$ \\ Noriyasu Hirasawa ${ }^{a}$ \\ ${ }^{a}$ Graduate School of Pharmaceutical Sciences and ${ }^{b}$ Graduate School of Dentistry, Tohoku University, Sendai, \\ ${ }^{\mathrm{c}}$ Faculty of Education, Ibaraki University, Mito, ${ }^{\mathrm{d}}$ Department of Bioactive Molecules, Gifu Pharmaceutical

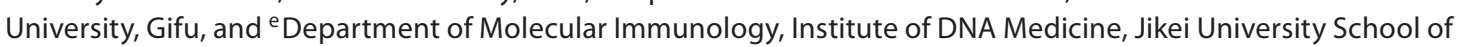 \\ Medicine, and fLaboratory Animal Research Center, Institute of Medical Science, University of Tokyo, Tokyo, Japan; \\ 'Laboratory of Molecular Immunology, National Heart, Lung, and Blood Institute, NIH, Bethesda, Md., USA
}

\section{Key Words}

Allergic inflammation - Thymic stromal lymphopoietin • Xylene

\begin{abstract}
Background: Some chemical compounds in the environment worsen allergic inflammation. In this study, we examined whether organic solvents induce the production of thymic stromal lymphopoietin (TSLP) which elicits Th2-type immune responses. Methods: Organic solvents were painted on the earlobes of BALB/c mice. The expression of TSLP in the ear was determined by ELISA. Results: Xylene and toluene, but not chloroform or ethyl acetate, induced the expression of mRNA for TSLP in the earlobe tissue. Among the aromatic compounds, xylene, especially $m$-xylene, and trimethylbenzene caused apparent TSLP production. The level of TSLP in the xylene-treated earlobes reached a maximum at $24 \mathrm{~h}$, and TSLP was expressed in epithelial tissues. Production of TSLP was unaffected in mast cell-deficient $\mathrm{W} / \mathrm{W}^{\mathrm{V}}$ mice but apparently diminished in TNF- $\alpha$ knockout mice and IL-4 receptor knockout mice. Repeated painting of xylene for 7 days induced an increase in the weight of cervical lymph nodes and expression of OX40 ligand, both of which were inhibited in
\end{abstract}

TSLP receptor knockout mice. Xylene promoted the picryl chloride-induced thickening of the ear and IL-4 production, which were reversed in TSLP receptor knockout mice. Conclusion: Xylene induced TSLP production, resulting in an exacerbation of allergic inflammation. Thus, xylene might be a good tool for examining the roles of TSLP in eliciting allergy in experimental animals.

Copyright $\odot 2011$ S. Karger AG, Basel

\section{Introduction}

Recently, the number of patients with allergic diseases has been increasing. Exposure to several chemical compounds in the environment might worsen allergies. However, it remains unclear which chemicals modify immune responses and how.

Thymic stromal lymphopoietin (TSLP), an IL-7-like cytokine produced by epithelial cells [1] and mast cells [2], plays an important role in the initiation of allergic inflammation [3]. TSLP production is increased at inflamed sites in patients with severe asthma [4], atopic dermatitis [5] and allergic rhinitis [6]. The allergic inflammation in an animal model of asthma was significantly

\section{KARGER}

(C) 2011 S. Karger AG, Basel

Fax +41613061234 E-Mail karger@karger.ch www.karger.com www.karger.com/iaa
Correspondence to: Prof. Noriyasu Hirasawa

Graduate School of Pharmaceutical Sciences

Tohoku University

6-3 Aoba Aramaki, Aoba-ku, Sendai, Miyagi 980-8578 (Japan)

Tel. +81 22795 5915, E-Mail hirasawa@ mail.pharm.tohoku.ac.jp 
suppressed in TSLP receptor-deficient mice [7]. In addition, the intratrachial administration of Fc-TSLP receptor-fusion protein or anti-TSLP receptor significantly reduced eosinophil infiltration, hyperplasia, and Th2 cytokine production $[7,8]$. Lung-specific expression of TSLP induced asthma-like airway inflammation [9], and skinselective expression and intradermal injection of TSLP induced atopic dermatitis $[10,11]$. Thus, an excess of TSLP is enough to cause allergic inflammation.

TSLP induces the activation of immature dendritic cells, recruitment of mature dendritic cells into lymph nodes, and expression of the OX40 ligand (OX40L) [12], which triggers the differentiation of allergen-specific naive CD4+ T cells into inflammatory Th2 cells that produce IL-4, IL-5, IL-13 and TNF- $\alpha[12,13]$.

It has been reported that epithelial cells (e.g. airway epithelial cells and keratinocytes) and mast cells produce TSLP when stimulated with antigens, cytokines and Tolllike receptor ligands $[2,14-16]$. The production of TSLP by epithelial cells was significantly enhanced by TNF- $\alpha$ and/or IL-4 $[14,15]$. Authors have reported that the application of 12-O-tetradecanoylphorbol-13-acetate (TPA) to the earlobes of mice induced the expression of TSLP mRNA [17]. The findings indicated that the production of TSLP could be induced by nonimmunological stimulants such as chemical compounds.

The first cells to interact with chemical compounds in the environment are the epithelial cells of the respiratory system, digestive tract and skin. Therefore, chemicals that promote Th2-type reactions and worsen allergic inflammation might induce TSLP production by epithelial cells. To clarify the involvement of TSLP in the induction of Th2-type reactions, we used our novel allergic inflammation model using picryl chloride $(\mathrm{PiCl})$, a contactsensitizing chemical [17]. PiCl induced Th1-dominant contact hypersensitivity in the mice treated with cyclophosphamide, which causes blood eosinophils [18] and decreases the number of regulatory T cells [19]. However, the application of TPA after the sensitization with $\mathrm{PiCl}$, which induces TSLP production, shifted the PiCl-induced allergic inflammation from a delayed-type response to a biphasic response, increased the infiltration of eosinophils, and the cytokine milieu from Th1 to Th2 [17]. Thus, this model is useful for detecting the chemical such as TPA, which shifts the cytokine milieu from Th1 to Th2 by producing TSLP.

In this study, the activity of various organic solvents to elicit TSLP production was examined in vivo and xylene was found to potentially augment Th2-type allergic responses by inducing TSLP production.

\section{Animals and Methods}

\section{Animals}

Male BALB/c mice and C57BL/6 (5 weeks old), WBBF1 wildtype, and $\mathrm{W} / \mathrm{W}^{\mathrm{v}}$ mice were purchased from SLC (Shizuoka, Japan). The generation of TSLP receptor knockout mice (C57BL/6 background) has been described previously [20]. BALB/c TNF- $\alpha$ knockout mice (BALB/c background) were established from original TNF- $\alpha$ knockout mice [21]. IL-4 receptor $\alpha$-chain gene knockout mice (BALB/c background) [22, 23] were purchased from Immuno-Biological Laboratories, Co. Ltd. (Takasaki, Japan). The study protocol was approved by the Institutional Animal Care and Use Committee of Tohoku University (Permission No. 20-Pharma-Animal-22).

Assay of TSLP Production Triggered by Organic Solvents

The organic solvents used were benzene, chloroform, ethyl acetate, toluene, xylene, xylene isomers, 1,3,5-trimethylbenzene, and 1,2,4-trimethylbenzene (Wako Pure Chemical Industries, Osaka, Japan) and TPA (Sigma-Aldrich, St. Louis, Mo., USA). Twenty microliters of solvent or a $0.04-\mu \mathrm{g} / \mu \mathrm{l}$ TPA solution (3:1 in acetone:ethanol) was painted on the right earlobe of mice. Earlobe tissue was then punched out (diameter $5 \mathrm{~mm}$ ) at a specified time and weighed.

\section{Determination of the Expression of mRNA for TSLP in}

Earlobes

The total RNA of tissues was extracted using a GenElute Mammalian Total RNA Kit (Sigma-Aldrich) according to the manufacturer's instructions. The extracted RNA $(0.5 \mu \mathrm{g})$ was reverse-transcribed by using M-MLV reverse transcriptase (Invitrogen Co., Carlsbad, Calif., USA). PCR amplification of the cDNA was performed with Taq polymerase (Takara, Ohtsu, Japan) and specific primers. The sequences of the primers used and PCR conditions for the amplification of TSLP CDNA were: (forward) 5'-GAC AGC ATG GTT CTT CTC AG-3' and (reverse) 5'CTG GAG ATT GCA TGA AGG-3', 40 cycles of denaturation at $94^{\circ} \mathrm{C}$ for $1 \mathrm{~min}$, annealing at $57^{\circ} \mathrm{C}$ for $1 \mathrm{~min}$, and extension at $72^{\circ} \mathrm{C}$ for $1 \mathrm{~min}$. The murine glyceraldehyde 3 -phosphate dehydrogenase (GAPDH) gene (a housekeeping gene) was used as an internal standard. The sequences of primers used for the amplification of GAPDH cDNA were: (forward) 5'-TGA TGA CAT CAA GAA GGT GGT GAA G-3' and (reverse) 5'-TCC TTG GAG GCC ATG TAG GCC AT-3'. PCR was performed for 27 cycles, denaturation at $94^{\circ} \mathrm{C}$ for $0.5 \mathrm{~min}$, annealing at $57^{\circ} \mathrm{C}$ for $1 \mathrm{~min}$, and extension at $72^{\circ} \mathrm{C}$ for $2 \mathrm{~min}$.

Determination of TSLP Protein in the Tissue

The tissue samples were homogenated at $4^{\circ} \mathrm{C}$ in $10 \mathrm{vol}$ of phosphate-buffered saline by a Beads Cell Disrupter (MS-100, Tomy Digital Biology Co., Tokyo, Japan). The concentration of TSLP in the supernatant of the homogenate was determined by ELISA (R\&D Systems, Minneapolis, Minn., USA). The supernatant contains unidentified substances which nonspecifically bind to the biotin-labeled enzyme of the ELISA kit. Therefore, the level of TSLP in the supernatant was measured with or without a secondary antibody to recognize nonspecific binding. The value obtained with the homogenate of untreated earlobes was then subtracted from the data to give the increase in the level of TSLP. 


\section{Histological Analysis}

The earlobe tissue was excised $24 \mathrm{~h}$ after the painting of xylene and immediately fixed in $10 \%$ neutral buffered formalin and embedded in paraffin. The sections were immunostained or stained with hematoxylin and eosin. The immunostaining of TSLP was performed using a rabbit anti-human TSLP antibody (Santa Cruz Biotechnology Inc., Santa Cruz, Calif., USA) and the avidin-biotin-peroxidase system (Vector Laboratories Inc., Burlingame, Calif., USA).

\section{Determination of OX40L $m R N A$ Levels in Cervical}

Lymph Nodes

Xylene $(20 \mu \mathrm{l})$ was painted on the right ear of mice once or once a day for 7 days. Twenty-four hours after the last painting, the cervical lymph nodes were excised and weighed. cDNA was prepared as described above. The sequences of the primers used and conditions for the amplification of OX40L cDNA were as follows: (forward) 5'-CAG AGG AGC AGT TAC CAG AT-3' and (reverse) 5'CAG GAG CAT TTA CAG TCA GG-3', 31 cycles of denaturation at $94^{\circ} \mathrm{C}$ for $1 \mathrm{~min}$, annealing at $58^{\circ} \mathrm{C}$ for $1 \mathrm{~min}$, and extension at $72^{\circ} \mathrm{C}$ for $1 \mathrm{~min}$. The levels of mRNA for OX40L and GAPDH were quantitated by scanning densitometry, and the density ratio of the OX40L mRNA to the GAPDH mRNA was calculated.

\section{Induction of PiCl-Induced Allergic Inflammation and}

Determination of $I L-4$

The effects of xylene on PiCl-induced contact dermatitis were examined as reported [17]. Briefly, cyclophosphamide (Sigma-Aldrich) was dissolved in saline and injected subcutaneously at a dose of $150 \mathrm{mg} / \mathrm{kg}$ into TSLP receptor knockout mice and wildtype mice. Two days later, mice were sensitized with $50 \mu \mathrm{l}$ of a 7\% (w/v) PiCl solution (Nacalai Tesque, Kyoto, Japan; 3:1 in acetone:ethanol; day 0 ). Thereafter, $20 \mu \mathrm{l}$ of xylene was applied to the same site twice (days 5 and 10). On day 12, mice were challenged with $20 \mu \mathrm{l}$ of a $1 \%(\mathrm{w} / \mathrm{v}) \mathrm{PiCl}$ solution by painting it on the right earlobe. Ear thickness was measured with a dial thickness gauge (Peacock, Ozaki, Tokyo, Japan) at a specified time. A homogenate of earlobe tissues was prepared as described above and the level of IL- 4 was determined by ELISA (e-Biosciences Inc., San Diego, Calif., USA). Nonspecific binding was subtracted as described above.

\section{Statistical Significance}

The statistical significance of the results was analyzed with the Dunnett test or the Student-Newman-Keuls test for multiple comparisons. The results were confirmed by at least three independent sets of experiments.

\section{Results}

\section{TSLP Production Induced by Organic Solvents}

Various organic solvents were painted on the right earlobes of mice. Consistent with previous findings [17], TPA induced the expression of TSLP mRNA in the earlobes excised $4 \mathrm{~h}$ after the painting (fig. 1). Under these conditions, the application of toluene and xylene, but not chloroform or ethyl acetate, induced the expression of

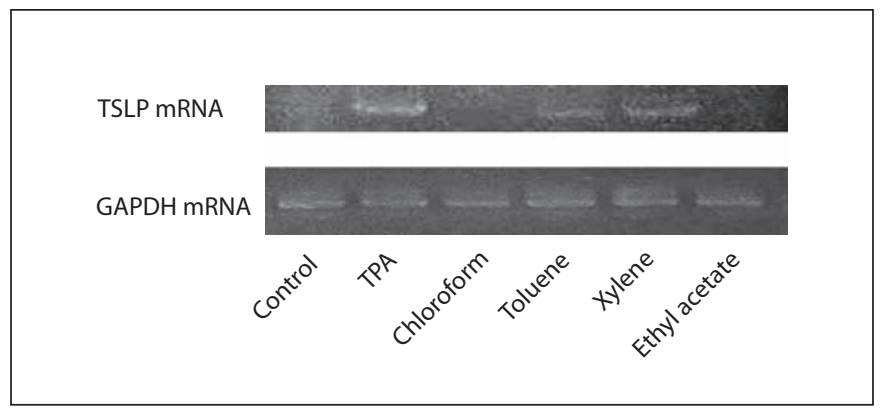

Fig. 1. Effects of chemical compounds on the expression of TSLP mRNA. Twenty microliters each of a $0.04 \mu \mathrm{g} / \mu \mathrm{l}$ TPA solution, chloroform, toluene, xylene and ethyl acetate were painted on the earlobes of BALB/c mice. Four hours later, total RNA was extracted from the excised earlobe tissue and the mRNAs for TSLP and GAPDH were detected by RT-PCR.

Table 1. Induction of TSLP by organic solvents

\begin{tabular}{lc}
\hline Organic solvent & $\begin{array}{c}\text { TSLP (increase vs. } \\
\text { untreated), pg/ml }\end{array}$ \\
\hline No solvent & $0 \pm 74$ \\
Benzene & $53 \pm 96$ \\
Toluene & $249 \pm 68^{*}$ \\
Xylene & $579 \pm 128^{* *}$ \\
$o$-Xylene & $154 \pm 68$ \\
$m$-Xylene & $801 \pm 145^{* *}$ \\
$p$-Xylene & $345 \pm 90^{* *}$ \\
1,2,4-Trimethylbenzene & $2,178 \pm 279^{* *}$ \\
$1,3,5$-Trimethylbenzene & $1,531 \pm 184^{* *}$
\end{tabular}

Organic solvents $(20 \mu \mathrm{l})$ were painted on the right earlobe of $\mathrm{BALB} / \mathrm{c}$ mice. The earlobe tissue was excised $24 \mathrm{~h}$ after the painting and the level of TSLP in the tissue homogenate was determined by ELISA. Data are shown as the mean \pm SEM for $6-10$ mice. Statistical significance: ${ }^{*} \mathrm{p}<0.05$ and ${ }^{* *} \mathrm{p}<0.01 \mathrm{vs}$. with no solvent.

TSLP mRNA (fig. 1). The effects of aromatic compounds on the production of TSLP protein were then examined. TPA also induced the increase in TSLP protein in the homogenate of earlobe tissue excised $24 \mathrm{~h}$ after the painting, and the amount of TSLP (increase vs. untreated) was 515 $\pm 18 \mathrm{pg} / \mathrm{ml}$. Xylene but not benzene increased the level of TSLP in the homogenate (table 1). The level of activity of toluene was in between that of xylene and benzene. Because the xylene used was a mixture of 3 isomers, $o$-xylene, $m$-xylene and $p$-xylene (1:5:3), the activity of each isomer was determined. Interestingly, $m$-xylene induced 
Fig. 2. Induction by xylene of TSLP production in earlobe tissue. a Xylene $(20 \mu \mathrm{l})$ was painted on the right earlobe of $\mathrm{BALB} / \mathrm{c}$ mice. TSLP levels were determined at the indicated time points after the treatment. Data are shown as the mean \pm SEM for 4-5 mice, ${ }^{* *} \mathrm{p}<0.01$ versus time 0 . b Xylene was painted on the earlobes of WBBF1 $\mathrm{W} / \mathrm{W}^{\mathrm{v}}$ mice and the corresponding wildtype mice (grey columns). The earlobes were excised $24 \mathrm{~h}$ after the treatment. $\mathrm{N}=$ Non-treated group. Data are shown as the mean \pm SEM for 5 mice, ${ }^{* *} \mathrm{p}<0.01$ versus the corresponding $\mathrm{N}$.
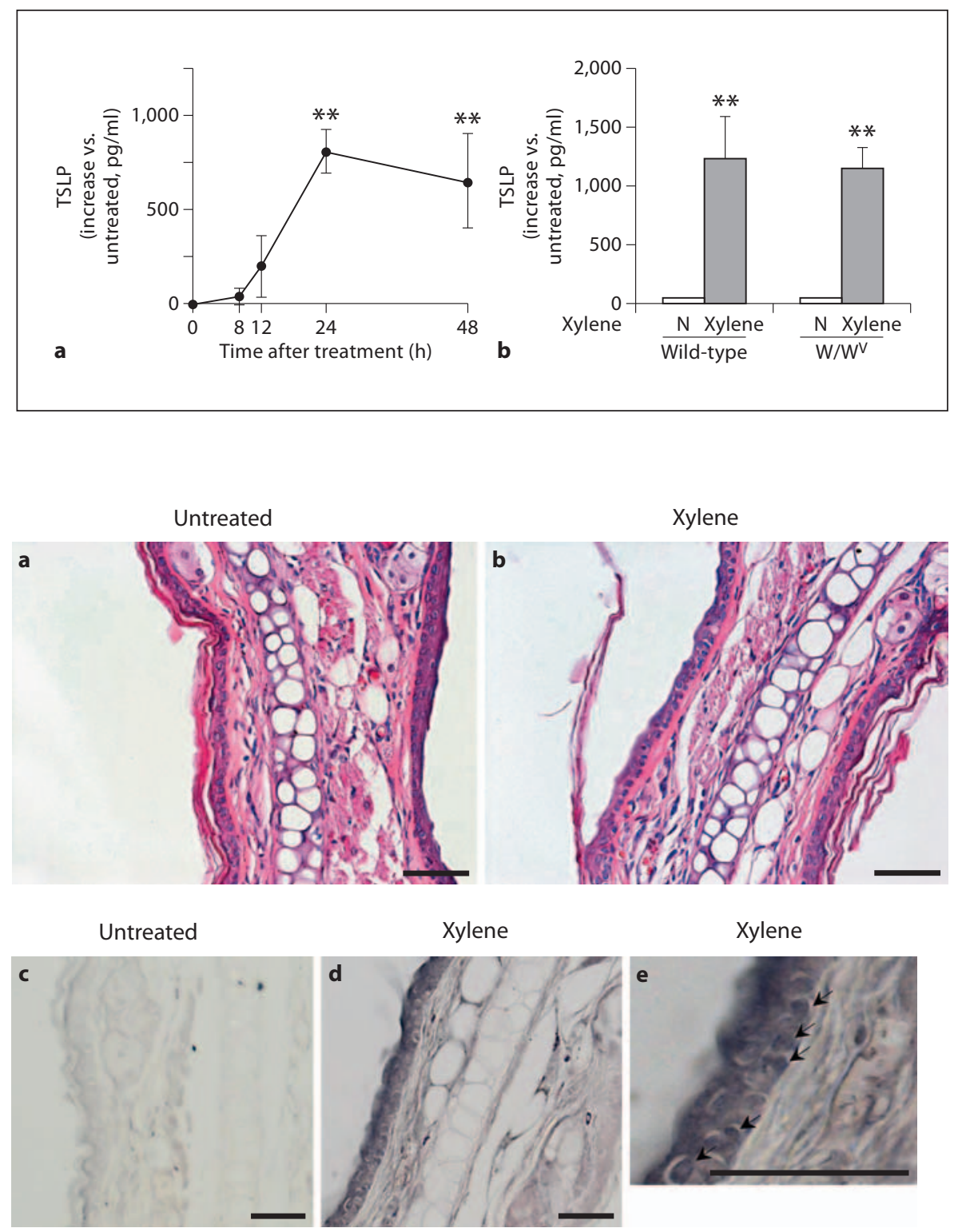

Fig. 3. Histochemical analysis of TSLPproducing cells. Xylene was painted on the right earlobe of BALB/c mice. The tissue of right earlobe tissue (b, d, e) and the left earlobe (untreated ear, a, c) were excised $24 \mathrm{~h}$ after the treatment. Tissue sections were stained with hematoxylin and eosin (a, b) and anti-TSLP antibody (c-e). e This is a higher magnification of $\mathbf{d}$. The positive cells were indicated with arrows. The scale bar represents $100(\mathbf{a}, \mathbf{b})$ and $50 \mu \mathrm{m}(\mathbf{c}-\mathbf{e})$.
$\mathrm{W} / \mathrm{W}^{\mathrm{v}}$ mice caused the production of TSLP at $24 \mathrm{~h}$ to almost the same extent as in the corresponding control mice (fig. 2b). The painting of xylene almost did not induce the infiltration of leukocytes (fig. 3a, b). The immunostaining with anti-TSLP disclosed that the TSLP-producing cells were mainly located in the epithelial layer of the xylene-treated ear (fig. 3d, e).

Involvement of TNF- $\alpha$ and IL-4 in the Xylene-Induced Production of TSLP

To clarify whether TNF- $\alpha$ and IL- 4 enhanced xyleneinduced production of TSLP, xylene was painted on the 
Fig. 4. Xylene-induced production of TSLP in earlobes of TNF- $\alpha$ knockout mice and IL-4 receptor knockout mice. Xylene (20 $\mu \mathrm{l})$ was painted on the right earlobe of $\mathrm{BALB} / \mathrm{c}$ wild-type mice and TNF- $\alpha$ knockout mice (TNF- $\alpha \mathrm{KO}$; $\mathbf{a}$ ) and IL-4 receptor knockout mice (IL-4R KO; b). The earlobes were excised $24 \mathrm{~h}$ later. The concentration of TSLP in the supernatant of the earlobe homogenate was determined by ELISA. Data are shown as the mean \pm SEM for 7 mice, ${ }^{*} \mathrm{p}<0.05,{ }^{* *} \mathrm{p}<0.01$ versus without xylene $(-),{ }^{\# \#} \mathrm{p}<0.01$ versus with xylene (+) in wild-type mice.

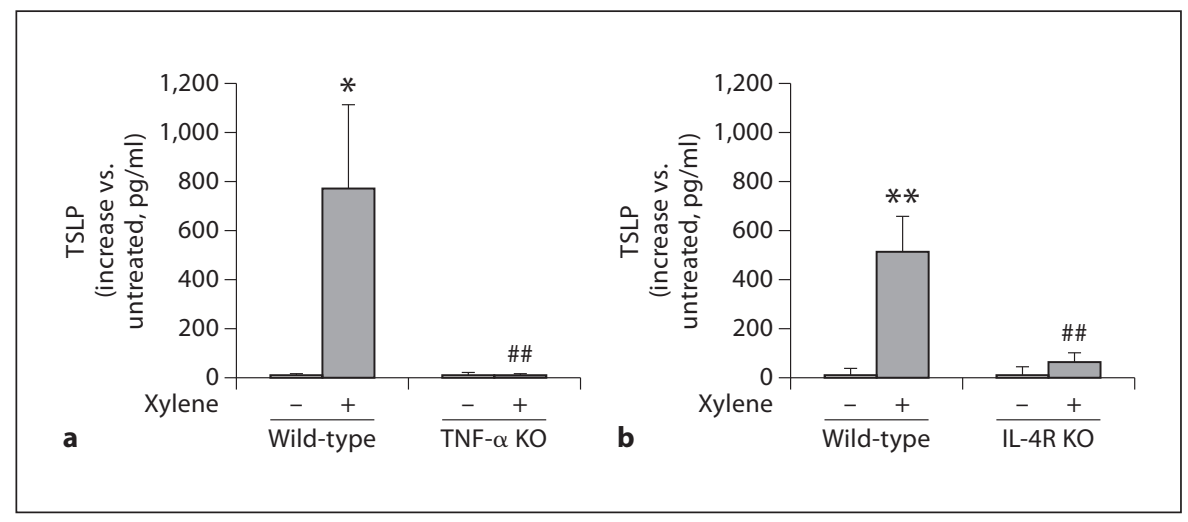

earlobes of TNF- $\alpha$ knockout mice and IL-4 receptor knockout mice. In these knockout mice, xylene-induced TSLP production was significantly diminished (fig. 4).

Increase in the Weight of Cervical Lymph Nodes and Expression of OX40L on the Painting of Xylene

To clarify whether or not xylene caused the production of a significant amount of TSLP to activate dendritic cells, the weight of the cervical lymph node and the expression of OX40L were determined. Although not significantly increased 1 day after the painting of xylene, the weight of the cervical lymph node was significantly greater following repeated treatment with xylene for 7 days (fig. 5a). The xylene-induced increase was smaller in C57BL/6 mice (fig. 5b) than in BALB/c mice, and partially but significantly reduced in TSLP receptor knockout mice (fig. 5b). In addition, the level of OX40L mRNA in the lymph node was apparently increased by the repeated treatment with xylene in wild-type mice but not in TSLP receptor knockout mice (fig. 5c, d).

\section{Exacerbation of PiCl-Induced Allergic Inflammation} by Xylene

Finally, the possibility was examined that xylene exacerbated antigen-induced allergic inflammation via TSLP production. As shown in figure 6a, the painting of xylene on the same earlobes 5 and 10 days after the sensitization with $\mathrm{PiCl}$ enhanced the $\mathrm{PiCl}$-induced increase in ear thickness. The levels of IL- 4 in the earlobe tissue $24 \mathrm{~h}$ after the challenge were also increased by the application of xylene (fig. 6b). The enhancement by xylene of ear swelling and IL-4 production was not observed in TSLP receptor knockout mice (fig. 6).

\section{Discussion}

TSLP is a master cytokine inducing Th2-type allergic inflammation [3]. In our study, some organic chemicals, i.e. volatile solvents used in paints and glues, induced production of TSLP, resulting in an exacerbation of allergic inflammation.

Among the organic solvents tested, xylene, especially $m$-xylene, 1,3,5-trimethylbenzene and 1,2,4-trimethylbenzene significantly caused the production of TSLP in vivo (fig. 1, table 1). Interestingly, the activity to induce TSLP production was highly dependent on the position of methyl groups on the benzene ring. Namely, $m$-xylene induced much more extensively the production of TSLP than did $o$-xylene. These findings suggested that xylene triggered TSLP production by binding to a specific protein in a structure-dependent manner, and not via physical and/or chemical toxicity.

The TSLP-producing cells were mainly epithelial cells and mast cells $[1,2]$. In addition, mast cells induced epithelial TSLP production in a model of allergic rhinitis [24]. However, the painting of xylene on the earlobes of mast cell-deficient $\mathrm{W} / \mathrm{W}^{\mathrm{v}}$ mice caused the production of TSLP to almost the same extent as in the corresponding control mice (fig. 2b), indicating that mast cells were not involved in the xylene-induced production of TSLP. The painting of xylene almost did not induce the infiltration of leukocytes, indicating that the cells existing in the skin might be producing TSLP. The immunostaining analysis disclosed that the TSLP-producing cells were mainly located in the epithelial layer of the xylene-treated ear (fig. 3d, e). These findings suggested that the cells, such as keratinocytes, in the epithelial layer produced TSLP in response to xylene.

TNF- $\alpha$ and IL- 4 only slightly induced production of TSLP but enhanced Toll-like receptor ligand-induced 


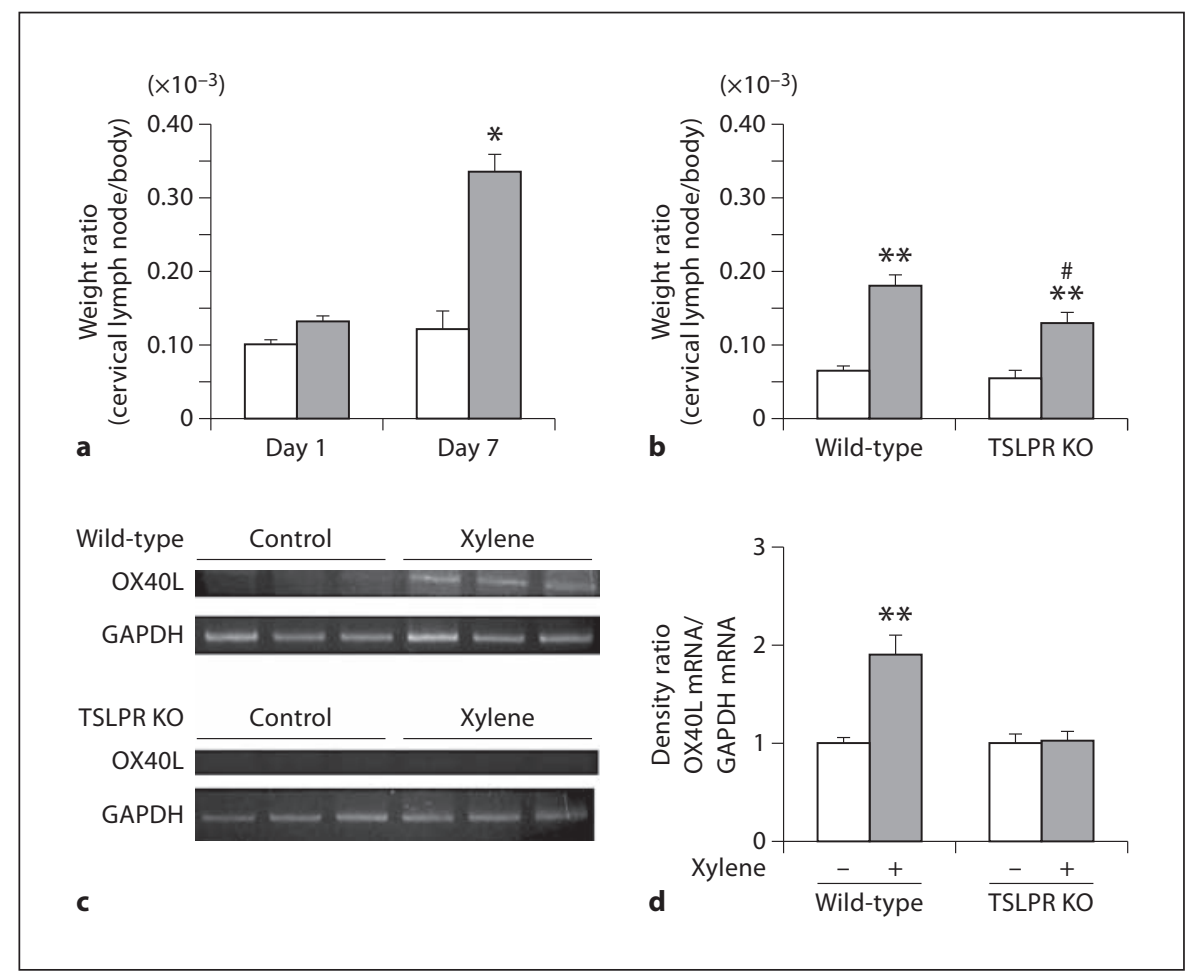

Fig. 5. Xylene-induced increase in the weight of the cervical lymph node and expression of OX40L. a, b Xylene was painted on the earlobe of BALB/c mice once or once a day for 7 days (a) or of TSLP receptor knockout mice and the corresponding wild-type mice (C57BL/6) once a day for 7 days (b). The cervical lymph nodes were excised $24 \mathrm{~h}$ after the last treatment. The weight of the cervical lymph node relative to body weight was determined. Grey columns indicate the xylene-treated group and open columns indicate the untreated group. Data are shown as the mean \pm SEM for 5 mice, ${ }^{*} \mathrm{p}<0.05,{ }^{* *} \mathrm{p}<0.01$ versus the corresponding

production in vitro [14-16]. No increase in the levels of these cytokines in the earlobe tissue obtained 4-24 h after the painting of xylene was detected (data not shown). However, xylene-induced production of TSLP was significantly diminished in TNF- $\alpha$ knockout mice and IL-4 receptor knockout mice (fig. 4), indicating that xylene elicited TSLP production via costimulation with basal or low levels of TNF- $\alpha$ and IL-4. The producing cells of TNF- $\alpha$ and IL- 4 might be the responding cells to xylene, but they were not identified via the immunostaining (data not shown). These findings also suggested that there is a common pathway triggered by xylene and Toll-like receptor ligands. The molecular mechanisms by which xylene induces TSLP production are under investigation.

TSLP induces the expression of OX40L on dendritic cells [12] and the proliferation of Th2 lymphocytes [12, untreated group, ${ }^{\#} \mathrm{p}<0.05$ versus the corresponding wild-type mice. c, d The expression of OX40L mRNA in the lymph nodes excised from wild-type mice and TSLP receptor knockout mice treated with xylene for 7 days was determined by RT-PCR. Data indicate the results for 3 mice in each group. The density ratio of OX40L mRNA to GAPDH mRNA was calculated (d). The mean density ratio of the untreated group was set to 1.0. Data are shown as the mean \pm SEM for 3 mice, ${ }^{* *} \mathrm{p}<0.01$ versus the corresponding untreated group.

13]. In the previous model, xylene increased the weight of the cervical lymph node and the expression of OX40L (fig. 5). Because these responses were reduced in TSLP receptor knockout mice, it was likely that xylene triggered the activation of dendritic cells via the production of TSLP, resulting in an increase in the proliferation of lymphocytes in the cervical lymph nodes. Because the weight of the lymph node was increased by xylene in TSLP receptor knockout mice, the possibility that xylene induced the production of cytokines other than TSLP, which caused lymphocytes to proliferate, could not be ruled out.

Some chemical compounds, such as formalin, bind to proteins and act as a hapten to induce allergies. The antigenicity of xylene itself, however, has not been reported. It is possible that xylene exacerbated the antigen-induced 


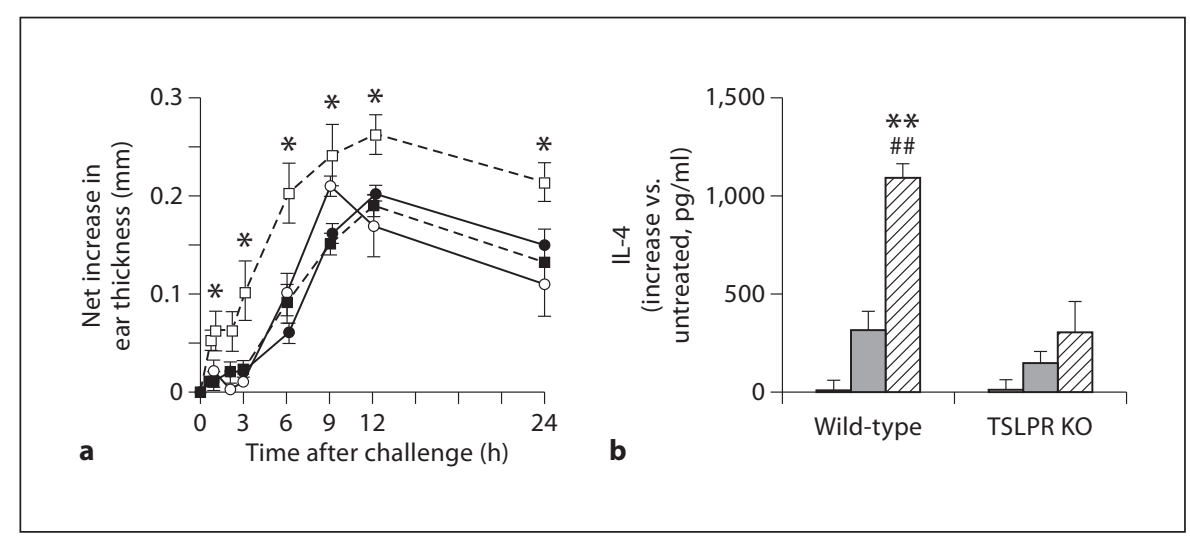

Fig. 6. Exacerbation of $\mathrm{PiCl}$-induced allergic inflammation by $\mathrm{xy}$ lene. a C57BL/6 wild-type mice (squares) and TSLP receptor knockout mice (circles) were pretreated with cyclophosphamide $(150 \mathrm{mg} / \mathrm{kg})$ on day -2 and $50 \mu \mathrm{l}$ of a $7 \%(\mathrm{w} / \mathrm{v}) \mathrm{PiCl}$ solution was painted on the right earlobe on day 0 . The sensitized mice were treated with xylene at the same site on days 5 and 10 (open symbols) or left untreated (closed symbols). On day 12, mice were challenged with $20 \mu \mathrm{l}$ of a $1 \%(\mathrm{w} / \mathrm{v}) \mathrm{PiCl}$ solution painted on the right earlobe. Earlobe thickness was measured 0-24 h after the challenge. Ear thickness before the challenge was subtracted from the data. Data are shown as the mean \pm SEM for 5 mice, ${ }^{*} \mathrm{p}<$ 0.05 versus the corresponding $\mathrm{PiCl}$-treated group. $\mathbf{b}$ The concentration of IL-4 in homogenate of the earlobe tissue excised $24 \mathrm{~h}$ after the $\mathrm{PiCl}$ challenge was determined by ELISA. Open columns, hatched columns and grey columns indicate the untreated group, $\mathrm{PiCl}$-treated group and $\mathrm{PiCl}+$ xylene-treated group, respectively. Data are shown as the mean \pm SEM for 5 mice, ${ }^{* *} \mathrm{p}<0.01$ versus the corresponding untreated group, ${ }^{\# \#} \mathrm{p}<0.01$ versus the corresponding PiCl-treated group.

flammation [26]. Therefore, the inhalation of these organic solvents may also induce TSLP production in respiratory tissue and exacerbate asthma and allergic rhinitis. Authors have now begun studying this possibility.

In conclusion, xylene induced the production of TSLP and aggravated allergic inflammation. This is the first report of a pure chemical compound detected in the environment triggering TSLP production and worsening allergic inflammation in vivo. The models employed here would be useful for detecting chemicals that exacerbate allergic inflammation without antigenicity. In addition, xylene might be a good tool for examining the role of TSLP in eliciting allergy in experimental animals.

\section{Acknowledgements}

This study was supported in part through a grant of the Long Range Research Initiative (LRI) by the Japan Chemical Industry Association (JCIA), Grant-in-Aid for Challenging Exploratory Research (22659025) from the Japan Society for the Promotion of Science, and by the Division of Intramural Research, National Heart, Lung, and Blood Institute, NIH. 


\section{References}

-1 Sims JE, Williams DE, Morrissey PJ, Garka K, Foxworthe D, Price V, Friend SL, Farr A, Bedell MA, Jenkins NA, Copeland NG, Grabstein K, Paxton RJ: Molecular cloning and biological characterization of a novel murine lymphoid growth factor. J Exp Med 2000;192:671-680.

-2 Okayama Y, Okumura S, Sagara H, Yuki K, Sasaki T, Watanabe N, Fueki M, Sugiyama K, Takeda K, Fukuda T, Saito H, Ra C: FcepsilonRI-mediated thymic stromal lymphopoietin production by IL-4-primed human mast cells. Eur Respir J 2009;34:425-435.

3 Liu YJ: Thymic stromal lymphopoietin: master switch for allergic inflammation. J Exp Med 2006;203:269-273.

-4 Ying S, O’Connor B, Ratoff J, Meng Q, Mallett K, Cousins D, Robinson D, Zhang G, Zhao J, Lee T, Corrigan C: Thymic stromal lymphopoietin expression is increased in asthmatic airways and correlates with expression of Th2-attracting chemokines and disease severity. J Immunol 2005; 174:81838190.

$\checkmark 5$ Soumelis V, Reche P, Kanzler H, Yuan W, Edward G, Homey B, Gilliet M, Ho S, Antonenko S, Lauerma A, Smith K, Gorman D, Zurawski S, Abrams J, Menon S, McClanahan T, de Waal-Malefyt Rd R, Bazan F, Kastelein R, Liu Y: Human epithelial cells trigger dendritic cell mediated allergic inflammation by producing TSLP. Nat Immunol 2002;3:673-680.

-6 Miyata M, Hatsushika K, Ando T, Shimokawa N, Ohnuma Y, Katoh R, Suto H, Ogawa H, Masuyama K, Nakao A: Mast cell regulation of epithelial TSLP expression plays an important role in the development of allergic rhinitis. Eur J Immunol 2008;38:1487-1492.

7 Al-Shami A, Spolski R, Kelly J, Keane-Myers A, Leonard W: A role for TSLP in the development of inflammation in an asthma model. J Exp Med 2005;202:829-839.

8 Shi L, Leu SW, Xu F, Zhou X, Yin H, Cai L, Zhang L: Local blockade of TSLP receptor alleviated allergic disease by regulating airway dendritic cells. Clin Immunol 2008; 129:202210
9 Zhang K, Shan L, Rahman MS, Unruz H, Halayko AJ, Gounni AS: Constitutive and inducible thymic stromal lymphopoietin expression in human airway smooth muscle cells: role in chronic obstructive pulmonary disease. Am J Physiol Lung Cell Mol Physiol 2007;293:L375-L382.

10 Yoo J, Omori M, Gyarmati D, Zhou B, Aye T, Brewer A, Comeau M, Campbell D, Ziegler S: Spontaneous atopic dermatitis in mice expressing an inducible thymic stromal lymphopoietin transgene specifically in the skin. J Exp Med 2005;202:541-549.

-11 Jessup H, Brewer A, Omori M, Rickel E, Budelsky A, Yoon B, Ziegler S, Comeau M: Intradermal administration of thymic stromal lymphopoietin induces a T cell- and eosinophil-dependent systemic Th2 inflammatory response. J Immunol 2008;181:4311-4319.

12 Ito T, Wang YH, Duramad O, Hori T, Delespesse GJ, Watanabe N, Qin FX, Yao Z, Cao W, Liu YJ: TSLP-activated dendritic cells induce an inflammatory $\mathrm{T}$ helper type 2 cell response through OX40 ligand. J Exp Med 2005;202:1213-1223.

13 Liu YJ: Thymic stromal lymphopoietin and OX40 ligand pathway in the initiation of dendritic cell-mediated allergic inflammation. J Allergy Clin Immunol 2007;120:238 244.

14 Kato A, Favoreto Jr S, Avila PC, Schleimer RP: TLR3- and Th2 cytokine-dependent production of thymic stromal lymphopoietin in human airway epithelial cells. J Immunol 2007;179:1080-1087.

15 Bogiatzi SI, Fernandez I, Bichet JC, MarloieProvost MA, Volpe E, Sastre X, Soumelis V: Proinflammatory and Th2 cytokines synergize to induce thymic stromal lymphopoietin production by human skin keratinocytes. J Immunol 2007;178:3373-3377.

16 Allakhverdi Z, Comeau MR, Jessup HK, Yoon BR, Brewer A, Chartier S, Paquette N, Ziegler SF, Sarfati M, Delespesse G: Thymic stromal lymphopietin is released by human epithelial cells in response to microbes, trauma, or inflammation and potently activates mast cells. J Exp Med 2007;204:253-258.

- 17 Hirasawa N, Ohsawa Y, Katoh G, Shibata K, Ishihara K, Seyama T, Tamura S, Hong JJ, Ohuchi K: Modification of the picryl chloride-induced allergic dermatitis model in mouse earlobes by 12-O-tetradecanoylphorbol 13-acetate, and analysis of the role of histamine in the modified model. Int Arch Allergy Immun 2009;148:279-288.
18 Satoh T, Cheu QJ, Sasaki G, Yokozeki H, Katayama I, Nishioka K: Cyclophosphamideinduced blood and tissue eosinophilia in contact sensitivity: mechanism of hapteninduced eosinophil recruitment into the skin. Eur J Immunol 1997;27:85-91.

$>19$ Ikezawa Y, Nakazawa M, Tamura C, Takahashi K, Minami M, Ikezawa Z: Cyclophosphamide decreases the number, percentage and the function of CD25+CD4+ regulatory $\mathrm{T}$ cells, which suppress induction of contact hypersensitivity. J Dermatol Sci 2005;39: 105-112.

$>20$ Al-Shami A, Spolski R, Kelly J, Fry T, Schwartzberg P, Pandey A, Mackall C, Leonard W: A role for thymic stromal lymphopoietin in CD4(+) T cell development. J Exp Med 2004;200:159-168.

-21 Tagawa Y, Sekikawa K, Iwakura Y: Suppression of concanavalin A-induced hepatitis in IFN- $\gamma$ mice, but not in TNF- $\alpha$ mice. J Immunol 1997;159:1418-1428.

$>22$ Noben-Trauth N, Shultz LD, Brombacher F, Urban JF Jr, Gu H, Paul WE: An interleukin 4 (IL-4)-independent pathway for CD4+ T cell IL-4 production is revealed in IL-4 receptor-deficient mice. Proc Natl Acad Sci USA 1997;94:10838-10843.

-23 Noben-Trauth N, Paul WE, Sacks DL: IL-4and IL-4 receptor-deficient BALB/c mice reveal differences in susceptibility to Leishmania major parasite substrains. J Immunol 1999;162:6132-6140.

24 Miyata M, Hatsushika K, Ando T, Shimokawa N, Ohnuma Y, Katoh R, Suto H, Ogawa H, Masuyama K, Nakao A: Mast cell regulation of epithelial TSLP expression plays an important role in the development of allergic rhinitis. Eur J Immunol 2008;38:1487-1492.

25 Azuma K, Uchiyama I, Ikeda K: The risk screening for indoor air pollution chemicals in Japan. Risk Anal 2007;27:1623-1638.

26 Nakamura Y, Miyata M, Ohba T, Ando T, Hatsushika K, Suenaga F, Shimokawa N, Ohnuma Y, Katoh R, Ogawa H, Nakao A: Cigarette smoke extract induces thymic stromal lymphopoietin expression, leading to Th2-type immune responses and airway inflammation. J Allergy Clin Immunol 2008;122:1208-1214 